\title{
Using Critical Discourse Analysis (CDA) in Media Discourse Studies: Unmask the Mass Media
}

\author{
Emi Sahmeni ${ }^{1}$ and Nur Afifah ${ }^{2}$ \\ ${ }^{1}$ SDIT Babul Huda Kampar, Indonesia \\ ${ }^{2}$ U-Raise Academy, Pekanbaru, Indonesia \\ nurafifah@gmail.com
}

\section{ARTICLE HISTORY \\ Received : 2019-06-08 \\ Revised :2019-06-11 \\ Accepted :2019-05-25}

\section{KEYWORDS \\ $C D A$ \\ Media discourse \\ Ideology and Power \\ Van Dijk \\ Social actors}

\begin{abstract}
The purpose of this paper is to know how CDA unraveling the covert ideologies while researching the existence of power in media discourse studies. This study reviewed sixteen journal articles to examine the ways and methods to discover the social phenomenon while revealing the authentic identity of the social actors. It was found that CDA has been used extensively to unmask the ideologies which classify the oppressed group while presenting a positive image for the group with the highest authority. The theory proposed by Teun Van Dijk seems the most used theories used when it related to unmask media profiling. There are three elements in the theory of CDA Van Djik that plays an important role in the research is Macrostructure, superstructure and microstructure. This study manages to reveals that mass media play an essential role in the production of trust, prejudice and dominance over social contexts.
\end{abstract}

\section{Introduction}

The term discourse comes from Sanskrit, which (etymology) has the meaning 'to say' and 'speak'. The word turns into a discourse word. Thus, the word discourse can be given as words or speech. Moreover, understanding Discourse Analysis (DA) which consists of two words, namely analysis and discourse. Analysis according to the Indonesian Dictionary (KBBI) can be seen as an investigation of an event, an explanation that is reviewed further, discussed, a breakdown of a number of points from various parts, as well as a breakdown of an event or not at least to change inter-state linkages (Depdikbud, 1988: 32) .

While, Anton M. Moeliono (1988: 334) states that discourse is sentences that are interconnected by linking propositions with one another in a relationship of meaning. Discourse also has many complete forms in terms of words, sentences, paragraphs or books (Kridalaksana, 1983: 208). Discourse is "language above sentence or above clause". Characteristics of structural descriptions in discourse have different units, categories of systematic forms or different relationships research on discourse is not enough just on the basis of the dimensions of the text alone, because this text is the work of production that must be questioned as well.

Further, He stated that the discourse was actually an abstract theoretical construct. Discourse analysis is the study of the structure of messages in communication. More precisely, discourse analysis is a deeper understanding of the various functions (pragmatics) of language. Discourse analysis (DA) was born from the awareness regarding problems contained in communication which are not limited to the use of sentences or sentence parts, speech functions, more complex and has a coherent message structure. Discourse analysis cannot be separated from the use of the rules of various branches of language, such as semantics, syntax, and so on. (Alex Sobur, 2004). Discourse analysis aims to describe the rules of sentence, language, and meaning.

Furthermore, Sinclair and Coulthard (1979) reveal that the new language means when in a context, in the discourse of analysis there are at least 3 views on the first language positivism-empirical, second constructive, the third critical view. When it talks about media studies, then the third view will be a wise choice since it offers a deeper and sensitive approach in analyzing meaning through media. Therefore, Critical Discourse Analysis got its fame. Figure in developing critical discourse analysis are Fairclough, Wodak and Teun Van Djik. Moreover, Van Dijk model could be the most comprehensive and often used in various media compared other researcher in the same field regarding a comprehensive analysis on how the news text is produced, both in relation to individual journalists and from the public. (Eriyanto 2006: 224).

The critical analysis in language studies came into existence which is commonly known as Critical Discourse Analysis (CDA), Critical Discourse Studies has appeared .i.e., $\mathrm{CDA}$ as a branch of discourse analysis that seeks beyond how and why discourse 
cumulatively contributes to the reproduction of macrostructures and underlines the traces of cultural and ideological meaning.

The term 'critical' in discourse has been addressed in multiple ways which regard to the use of language and the reproduction of power in society. The criticality is designated specifically to the issue of power, hegemony and resistance in various fields of language.

Van Dijk (2003) stated that CDA focuses on how a social group's mental representation is influenced by social structures. In this occasion, the theme of a discussion may influence how people emphasize the important information in a text or talk. CDA is characterized as an interdisciplinary multi-methodical approach rather than an isolated discipline on its own. Van Dijk (2009) asserted that CDA is a combination of critical theory and application rather than a critical analysis, which therefore leads to the term (critical discourse studies).

Van Dijk (2009) and Wodak and Meyer (2009) sketched the aims and tenets of CDA which are employed in reviewing recent CDA studies:

a) CDA is more problem-oriented than in a particular theory or discipline because its implications are explicitly presented in layman's terms to the public.

b) CDA is interdisciplinary because it involves various theories, methods and practical applications in serious non-binding issues and problems in society.

c) $\mathrm{CDA}$ is considered social research because its critical research is concerned with social issues and understanding of human rights, social inequality, abuse of power, such as racism, classism, sexism, and so on.

d) CDA is interested in unethical issues that investigate the dominance of groups of people who experience discursive injustice.

e) CDA underlines spontaneous assessment as a need to enlighten the phenomenon under investigation and justifies why a certain interpretation is more effective than others. The purpose of this review is to find out how CDA as a critical discourse analysis method plays a central role in uncovering hidden ideologies and examining the power of media discourse studies. The specific objective is to explore the application of the CDA approach in the study.

\subsection{CDA Theory and Approach}

The theories proposed by Van Dijk presents in a variety of social theories and models used in CDA, which unleash the various ideological notions.

\subsubsection{Macrostructure}

Macrostructure shows the dominant, central, and important power in a mass media topic. The observed element is a thematic or a topic, on the information to be conveyed, the mass media will create topics that add to the reader's thirst for information being preached and on the topic will also see how journalists drag public opinion in their writings.

As an example of the hottest topic that is being spread in Indonesian society is the move of the capital city to be pros and cons, one of the mass media, namely compass, published news about the president's speech with the title "Ibu kota RI pindah, Jokowi tegaskan bukan salah Pemprov DKI" from the topic of news The reporters want the public to trust the words of Jokowi from the word "affirm" but here we also see that reporters use the word "move" instead of "moved" if a look at the whole topic then put the news Jokowi in the eyes of the public as a mediator instead of the perpetrators who caused the move of the capital then here will come out speculation that this has something to do with the DKI provincial government but this does not fully show the purpose of the reporting purpose requires many elements that need to be seen in addition to the implicit implications contained in the topic also the choice of words to understanding the contents of the topic but a little lack of topics can give an idea on which side the communicator wants to position the public.

Behold Van Dijk's idea, which states that the writing of the topic is done following a certain mental or thought with a specific purpose. Behold Van Dijk's idea, which states that the writing of the topic is done following a certain mental or thought with a specific purpose.

\subsubsection{Superstructure}

Superstructure or schematic according to Van djik is a journalist's strategy in arranging the composition of the news to achieve the flow that leads to the purpose of the news by prioritizing the pressures on the most important things such as a report that preaches about student demonstrations that students want to highlight is a demonstration anarchist, the flow that will be written by the first journalist is the loss of the demonstration, the victims of the demonstration and the actions of the participants of the demo to the point of view of the disadvantage community, the journalist will write the reasons for the demo, the trigger of the demo at the end of the news so that public opinion is more focused on the initial reporting describing the demo anarchist but different if journalists want to convey in the point of view of students who are demo then the composition of the writing begins with the initial atmosphere of the demo, the reasons for the demo, the demo message to be conveyed to the cause of the chaos 
of the demo then the public opinion in the sleigh that the demo goes peacefully, but there is a person who triggers up the inevitable chaos. From a schematic point of view, the journalist has the ability to choose what, who and how a story should highlight one side that is wanted; this also applies to political reporting. Journalists can choose who they want to highlight or what they want to show in their reporting.

\subsubsection{Microstructures}

More detailed microstructures in the form of semantics, syntax, stylistics, rhetoric. Semantics is the study of linguistics that discusses the meaning (lyon, 1971: 1) in the study of Van djik semantics intended to suppress the meaning of the text by giving detailed information on one side or making explicit and reducing information on the other hand how this is done then there are several the element that influences semantics is the background of the formation of text or news. The setting can be a justification for reporting, therefore by analyzing the setting, the meaning or purpose is easier to uncover. Reflection from this setting has an ideological reflection because it illustrates that the news will be taken. The second part of the element that must be observed is the detailed discourse According to Eriyanto (2011: 238) is a person's ability to control information that is important to be issued with consideration of bringing adVan tages or disadVan tages to the communicator even sometimes the news tends to be excessive, the news that requires detailed discourse has an implicit element that is sometimes unnoticed by the reader but has great effect on the reader.

In semantics, there are also elements of intent where these elements have in common with elements of detail, but in this element are more likely to profit will be spelt out clearly or explicitly clear and explicit and close or issue information that is implicitly detrimental. Like a piece of news about a party elite, the people of this media are the figures of the party that will be reported. The news will provide information that can benefit the image of the party. The second part of the syntax is in the form of sentences, coherence, pronouns. The following example sentence form "a teacher in a private school beats his students" with the sentence "students from one private school beaten by his teacher" the use of both forms of sentences is correct but can be seen in which part of the sentence to highlight the active sentence in general position someone as the subject of the response while passive sentences place a person as an object. Coherence is a relationship or interwoven words, coherence becomes an element formed from the perspective of the media whether a news is connected or separated from each other such as "an event A happened in country $\mathrm{C}$ has a good impact, event A happening in country $\mathrm{B}$ has a negative effect "to connect an event, the sentence will read" different from country
C, event A has a negative effect on country B "or the opposite sentence shows the good effect of all that depends on the angle where the media want to highlight it.

The pronouns are elements that can manipulate for example the use of the word "we" with "them" "we as a nation that wants peace for this country" the impression of the sentence is more friendly and solid, "they as a nation that one wants peace for this country" said "They" give distance and sense of alien to the recipient of the info and will cause negative speculation or implicit meaning in the sentence. Furthermore,the fourth part of the microstructure is a structure that is how the choice of words used in media texts, the choice of words can indicate certain attitudes and ideologies such as "the Israeli slaughter of Palestinian children" "a corrupt apparatus "Words like "slaughter" indicate a word that means an affirmation of an extreme action.

Finally, the microstructure element is rhetorical, namely how and in what way an event is emphasized on the text, for example, the emphasis uses the metaphor of "the silent world of a thousand languages, Palestine screaming" or the use of graphic examples showing graphical graphics annually and also in graphics can include photos or images.

\subsection{Social Theory of Discourse}

The social theory of discourse is linguistically oriented as it purposes in examining social and political event in society. In this theory, discourse is viewed as a social practice which establishes power between a varieties of entities. Actually, this leads to the rise of power and ideological practice in society which offers power in discourse and signifies a variety of world views from diverse perspectives.

Social analysis in Van Djik's view is a growing discourse in the community in this case a text must be examined using intertextual analysis so that it will be seen how the discourse is shaped and developed in public life as well as reporting on human rights violations so the need for discourse research on the law Human rights and how human rights are viewed by the ends of this analysis to show the meaning that can be captured together, with the practice of discourse and the legitimacy of the formation of social power. In the social analysis, Van Dijk argues that there are 2 important points, the first is power, in this case, Van Dijk defines power as ownership of a group, the dominant attitude of a group in other groups as in the case of white groups with blacks. The second part is that access influences discourse, elite groups have greater access space than minority groups and also we can see the owners of a media more freely in accessing things that benefit them than those who do not own a media. 
In the social theory of discourse, Fairclough (1992) proposed 3 principles which are regarded as a social practice. "First, Discourse is both constitutive and constituted. Discourse is supposed to contribute to the shaping and reflection of social structures. Second, social practice constructs the social identities and the social relationships between various entities and classes in society. Third, social practice contributes to the system of knowledge and belief as it leads to other functions of language such as identity, relational and ideational functions. Moreover, the emphasis is on the dialectical relationship, which comprises the relationship between social structure and social practice and event and semiotics (Fairclough, 2009). The dialectical practice manifested sees social practice and event as contradictory due to its complex relationship. As a whole, social theory of discourse is concerned with how discourse bonds with society while focusing on the interaction patterns between participants, social goals and types of social events".

\subsection{Theory of Ideology}

The ideological theory is considered a multidisciplinary approach, which is the basic framework for organizing some ideological and consumption concepts. "Ideology usually controls the thinking of social groups which then represent the basic social characteristics of groups based on their identity, purpose, norms, values, positions and resources" (Van Dijk, 1995). With regard to ideological consumption, cognitive and social factors are also involved in this process. Van Dijk (1995) proclaims that "social cognition is a system with shared sociocultural knowledge by members of a particular group, society or culture. For example, feminists share ideas or beliefs about principles such as positive acts of abortion and stereotypes by men@. Therefore, these principles lead to the emergence of feminist ideology. It is felt that ideology is acquired by members of social groups through a long-term process and through other forms of social information processing (Van Dijk, 1995). The component in the most important ideological representation is the existence of our term against them (Van Dijk, 1995) The relationship between these two components is significant as our term 3L: Journal of English Studies Southeast Asia - Vol 21 (2): 57 - 6860 associated with positive traits and they are associated with bad traits (Van Dijk, 1995).

Moreover, He mentioned also "the basic form of ideological nature that governs, monitoring and controlling social group attitudes is ideological. Each ideological representation is always accompanied by the experience of a person who is called a model". Van Dijk (1987) states that the model represents a personal experience such as certain information any event or action processed in short-term memory. In other words, the model Parallel to cognitive functioning because they observe one's thoughts and personality knowledge it has. Models are uniquely formed because they hold the ability to control the experience of a social actor (Van Dijk, 1995) and are also "Influenced by the cognitive processes of other group members in society. In connection with this, it is felt that the model is the main unit that controls the various actions of human life as the discovery of some ideologies".

\section{Method}

In conducting the analysis, first, an electronic database search is run in the ProQuest Scholarly Journal and Google Scholar database. The ProQuest database was chosen to search for related studies for this review as it is a reputable database and provides a variety of information covering multiple authoritative sources. Most importantly, ProQuest has subscribed with the university to give sufficient resources for students. In addition, Google Scholar is used because it is easily accessible and indexed literature through various disciplines. Search is limited to a ten-year period from 2005 to 2015, in choosing related studies for review.

Keywords such as critical discourse analysis and media are used to explore. The other criterion in choosing a related study for this review is based on the originality of data. Initially, 30 related studies have been downloaded from the ProQuest and Google Scholar databases. Of the 30 studies, 14 studies were eliminated in the absence of a concrete theoretical framework. Only studies that apply the CDA approach are included and reviewed. 16 research studies were read thoroughly, and their content was analyzed in accordance with the main theoretical framework. After analyzing the content of the selected study, the main framework used in the study was structured on three main themes. The first theme relates to the application of the CDA using the Fairclough analysis framework, and the second and third themes are related to the application of CDA using the Van Dijk framework. It has been noted that within a ten-year time frame, Wodak's theoretical framework in CDA is rarely used in related studies because of complex analytical procedures. The appendix shows a summary of research studies by author, publication year, research objectives, methodology, data sources and findings.

\section{Result and Discussion}

The study of political ideology, power, and discursive discourse has been investigated because there is an implicit connotation in every word and power behind every word in unmasking the identity of a noble character or a social leader. It is found that power is often associated with the act of controlling and limiting the contribution of participants who are not strong in society because this encounter usually occurs between the power holder and the lower class society. Literally, 
helpless people are not given the opportunity to comment or argue about the political issues and rationality of an event. It is perceived that ideology has the power to multiply non-critical discourse analysts in various ways in forcing a belief

In addition, it is felt that positive self-presentation and other negative presentation strategies are often used. Discriminative groups are described as another negative presentation because these groups are suppressed by a dominant group that has a positive selfpresentation. The study below is organized under three main themes related to Fairclough's analytical framework, ideological and ideological aspects of Van Dijk. The analytical framework for each study is determined by the researcher of a particular study. The analytical framework that the dominant researcher uses is the Van djik model where the text structure and social analysis and ideology show indications of the implications and interests of a group in order to create a support for the position in the view of the recipient of information and the CDA framework has a concern for the oppressed so that the use of CDA in very discourse help researchers analyze media texts.

\section{Conclusion}

These sixteen articles have shown that mass media play an important role in the production of trust, prejudice and dominance over social contexts because mass media tends to marginalize others and misinterpret an event. It was found that since CDA has gained popularity in the field of discourse studies, more and more studies have applied CDA to discursively investigate texts, interactions and social contexts, to explore the relationship between language and ideology, and to examine how ideologies that dominate oppresses are less strong. With this assumption, it is clear that CDA is a powerful tool in deconstructing texts as the scale of the ideological representations in question. To summarize, this review has examined various CDA behaviours aimed at expressing stereotypes, prejudices, hegemony, power and ideological attitudes.

The social context of representation determines the production of discourse, this is inseparable from the Van Dijk CDA model where the three elements are factors that always emerge when making news discourse while discourse contributes to the development of the social power of bound relations which is the value of success in the power of language using theory Van Diik as the most used theory among these sixteen articles. This present study hopes to contribute to existing knowledge about CDA research to raise awareness among new researchers who aspire to conduct CDA studies that employ macrostructure, superstructure and microstructure as reinforcement and connected elements in media studies.

\section{Acknowledgement}

The writers give their gratitude to anonymous reviewers and colleague who assisted immensely in the production of this research article, especially for their feedback and critique.

\section{References}

Ahmadian, M., \& Farahani, E. (2014). A Critical Discourse Analysis of The Los Angeles Times and Tehran Times on the Representation of Iran's Nuclear Program. Theory \& Practice in Language Studies, 4(10).

Alo, M. \& Orimogunje, A. (2013). Discourse strategies and ideology in selected radio lead news of Osun State Broadcasting Corporation, Nigeria. 3L: Language, Linguistics, Literature. 19(2), 111123.

Azad, O. (2013). Critical Discourse Analysis of 20: 30 News Broadcasting. Modern Journal of Language Teaching Methods. 3(2), 78.

Behnam, B., \& Mahmoudy, B. (2013). A critical discourse analysis of the reports issued by the International Atomic Energy Agency (IAEA) director-general on Iran's nuclear program during the last decade. Theory and Practice in Language Studies, 3(12), 2196.

Behnam, B., \& Zenouz, R. M. (2008). A contrastive critical analysis of Iranian and British newspaper reports on the Iran nuclear power program. Systemic Functional Linguistics in Use, 29, 199-218.

Bilal, H. A., Ahsan, H. M., Gohar, S., Younis, S. \& Awan, S. J. (2012). Critical discourse analysis of political TV talk shows of Pakistani media. International Journal of Linguistics. 4(1), 203219.

Bolte, S. \& Keong, Y. C. (2014). The Refugee Swap Deal in Malaysian Online News Reports: Ideology and Representation. GEMA Online of

Caldas-Coulthard, C. R. (2003). Cross-cultural representation of 'otherness' in media discourse. In Critical discourse analysis (pp. 272-296). Palgrave Macmillan, London.

Carroll, J. S., \& Freedle, R. O. (Eds.). (1972). Language comprehension and the acquisition of knowledge. Washington, D.C.: Winston.

Carvalho, A. (2008). Media (ted) discourse and society: Rethinking the framework of critical discourse analysis. Journalism Studies, 9(2), 161-177.

Classroom Discussion. Proceedings of ISELT FBS Universitas Negeri Padang, 3, 87-95. 
Cox, R. S., Long, B. C., Jones, M. I., \& Handler, R. J. (2008). Sequestering of suffering: Critical discourse analysis of natural disaster media coverage. Journal of health psychology, 13(4), 469-480.

Cox, R. S., Long, B. C., Jones, M. I., \& Handler, R. J. (2008). Sequestering of suffering: Critical discourse analysis of natural disaster media coverage. Journal of health psychology, 13(4), 469-480.

Eriyanto. (2001). Analisis Wacana: Pengantar Analisis Teks Media. Yogyakarta: LKiS.

Fairclough N (1995). Critical Discourse Analysis. The Critical Study of Language. London: Longman.

Fairclough, N. (1992). Discourse and Social Change (Vol. 73). Cambridge: Polity Press.

Fairclough, N. (2009). A dialectical-relational approach to critical discourse analysis in social research. In R. Wodak \& M. Meyer (2nd ed). Methods of critical discourse analysis (pp 162187). Thousand Oaks: Sage.

Fairclough, N. (2013). Critical discourse analysis: The critical study of language. Routledge.

Fairclough, N., \& Wodak, R. (1997). Critical discourse analysis. Discourse studies: A multidisciplinary introduction, 2, 258-284.

Faradila, F. (2008). A critical discourse analysis of gender bias in Mona Lisa Smile film (Doctoral dissertation, Universitas Islam Negeri Maulana Malik Ibrahim).

Fauzan, U., Subroto, H. E. \& Poedjosoedarmo, S. (2014). A CDA of the ideology of Indonesian metrotv news report. International Journal of Linguistics. 6(4), 71-86.

Hamuddin, B. (2015). DISCOURSE ON MEDIA: Bringing Hot News into ELT's Classroom Discussion. Proceedings of ISELT FBS Universitas Negeri Padang, 3, 87-95.

Iqbal, A., Danish, M. H. \& Iqbal, F. (2014). Critical discourse analysis of attributive words used with the word Muslim: A corpus based study.

Iqbal, A., Danish, M. H. \& Tahir, M. R. (2014). The exploitation of women in beauty products of Fair and Lovely: A critical discourse analysis study. International Journal on Studies in English Language and Literature. 2(9), 122-131.

Janks, H. (1997). Critical discourse analysis as a research tool. Discourse: Studies in the Cultural Politics of Education. 18(3), 329-342.
Jorgensen, M. W. \& Phillips, L. J. (2002). Discourse Analysis as Theory and Method. London. Sage.

Kaur, K., Arumugam, N. \& Yunus, N. M. (2013). Beauty product advertisements: A critical discourse analysis. Asian Social Science. 9(3), 61-71.

Kerr, P. K. (2009). Iran's Nuclear Program: Tehran Compliance with International Obligations. Congressional Research Service. USA: DIANE Publishing.

Kress, G. (1990). Critical discourse analysis. Annual review of applied linguistics, 11, 84-99.

Mayasari, M., Darmayanti, N. \& Riyanto, S. (2013). Critical discourse analysis of reporting on" Saweran for KPK Building" in media Indonesia Daily Newspaper. International Journal of Linguistics. 5(4), 213-224.

Pasha, T. (2011). Islamists in the headlines: Critical discourse analysis of the representation of the Muslim Brotherhood in Egyptian newspapers (Unpublished Doctoral dissertation). University of Utah, USA.

Rogers, R. (2004). An introduction to critical discourse analysis in education. In An introduction to critical discourse analysis in education (pp. 3148). Routledge.

Sobur, A. (2004). Analisis Teks Media: Suatu Pengantar untuk Analisis Wacana, Analisis Semiotik, dan Analisis Framing. Bandung: PT Remaja Rosdakarya.

Tahmasbi, S. \& Kalkhajeh, S. G. (2013). Critical discourse analysis: Iranian banks advertisements. Asian Economic and Financial Review. 3(1), 124-145.

Vaara, E., \& Tienari, J. (2002). Justification, legitimization and naturalization of mergers and acquisitions: A critical discourse analysis of media texts. Organization, 9(2), 275-304.

Vahid, H. \& Esmae'li, S. (2012). The power behind images: Advertisement discourse in focus. International Journal of Linguistics. 4(4), 36-51.

Van Dijk, T. A. (1995). Discourse analysis as ideology analysis. Language and Peace. 10, 47142.

Van Dijk, T. A. (2003). 18 Critical discourse analysis. In D. Tannen, D. Schiffrin \& H. Hamilton (Eds.), Handbook of discourse analysis. (pp. 352-371). Oxford: Blackwell.

Van Dijk, T. A. (2009). Critical discourse studies: A sociocognitive approach. Methods of critical discourse analysis. 2(1), 62-86. 
Van Dijk, T. A. (2001). 18 Critical discourse analysis. The handbook of discourse analysis, 352.

Van Leeuwen, T. (2008). Discourse and practice: New tools for critical discourse analysis. Oxford University Press.

Weiss, G., \& Wodak, R. (Eds.). (2007). Critical discourse analysis. New York, NY: Palgrave Macmillan.

Wodak, R., \& Meyer, M. (Eds.). (2015). Methods of critical discourse studies. Sage. 